\title{
The current status of Halophila beccarii: An ecologically significant, yet Vulnerable seagrass of India
}

\author{
${ }^{1}$ Amrit Kumar Mishra, ${ }^{1}$ Deepak Apte
}

${ }^{1}$ Marine Conservation Department, Bombay Natural History Society, Hornbill House, Dr. Salim Ali Chowk, Shaheed Bhagat Singh Road, Opp. Lion Gate, Mumbai, 400001, India

Corresponding author: a.mishra@bnhs.org

\begin{abstract}
:
We reviewed the current status of a Vulnerable seagrass, Halophila beccarii from the coast of India using the published data from 1977-2020. We found that the seagrass, $H$. beccarii has a pan India distribution on both east and west coast. It is abundant in the intertidal silty-muddy region on the west coast, while on the east coast it is found on sandy habitats, with few exceptions of muddy habitat. $H$. beccarii was found to be associated with mangroves or smaller seagrass species within a depth limit of $1.7 \mathrm{~m}$. Low salinity and high nitrate levels were observed for the $H$. beccarii meadows of the west coast due to its association with mangroves. The nutrient levels in $H$. beccarii meadows of India were comparatively lower than other seagrass meadows. Most of the research on $H$. beccarii has focoused on its morphometrics (41\%), reproductive (33\%) and distribution (29\%) along the coast of India. Reproductive traits such as flowering and fruiting varying according to the seasons of each coast due to the influence of monsoon and its associated temperature, salinity and nutrient influx. $H$. beccarii has a great potential of various bioactive compounds, which needs further investigation. Habitat disturbance, anthropogenic pollution and coastal development are the major cause of declining $H$. beccarii ecosystems in India. Significant loss of the seagrass was observed from the west coast of India due to increased coastal development activities. There is a significant need in quantifying $H$. beccarii population trends, impact of climate and anthropogenic stressors, economic values of ecosystem services and the role of ecological connectivity for better conservation and management of $H$. beccarii seascapes across India. There is a need for integration of research outcomes in policy framing for preventing the decline and further loss of this vulnerable seagrass ecosystem.
\end{abstract}


Keywords: Seagrass, Ocean Turf grass, climax communities, Indian Ocean region, IUCN, Population traits, conservation, management

\section{Highlights:}

- H. beccarii has a distribution on both east and west coast of India

- Habitat disturbance is the major cause for H. beccarii loss

- There is a critical lack of data on the population trends of $H$. beccarii

- Research on H. beccarii has declined after declared as Vulnerable

- Immediate actions on population trend is necessary to prevent further loss of $H$. beccarii 


\section{Introduction:}

Seagrasses are marine angiosperms (in the class Monocotyledoneae) that have evolved from terrestrial plants and have evolved physiological adaptation to survive underwater. These underwater marine plants form vast meadows found in all bioregions of the world except Antarctica and support a range of keystone and ecologically important marine species from all trophic levels (Orth et al., 2006). These ecosystems provide 24 different types of ecosystem services (Short et al., 2011; Nordlund et al., 2016) and contribute significantly to the health of coral reefs, mangroves, salt marshes and oyster reefs (Duke et al., 2007; Heck et al., 2008 Unsworth et al., 2010). The ecological interaction between seagrasses and the surrounding coral reef and mangrove ecosystems plays a significant role in stabilizing of the coastal environment, thus enriching the bio-physical support for other associated coastal communities (Kathiresan \& Alikunhi, 2011; Guannel et al., 2016; Mishra and Apte, 2020a). Seagrasses due to their high primary production acts as source of energy for various food webs of marine ecosystems, either through direct herbivory or through detritus cycle (Hemminga and Duarte, 2000). They also transfer nutrients ( $\mathrm{N}$ and $\mathrm{P}$ ) and organic carbon to the deepest parts of oceans that help in sustaining various trophic levels (Duarte et al., 2005). Their carbon sequestration capacity is 35 times faster than terrestrial plants and they store more carbon (Duarte et al., 2013) and contribute significantly to coastal "Blue Carbon" (McLeod et al., 2011) that helps in mitigation of climate change (Howard et al., 2014). Seagrass ecosystems form important habitat and nurseries for various fish population, endangered sea cows and seahorses (Green and Short, 2003; Cullen-Unsworth et al., 2018) that directly support artisanal fisheries and the livelihoods of millions of coastal communities in tropical regions (Björk et al., 2008; Nordlund et al.,2017). Along with supporting fisheries and acting as carbon sink, seagrass meadows protect the shoreline diminishing wave energy and trapping sediments (Ondiviela et al., 2014), 
regulating nutrient cycling (Costanza et al., 2014) and acting as bioindicators of coastal pollution (Lewis and Devereaux, 2009).

Additional ecosystem services of seagrasses include many features such as filtration of water from suspended sediments, recycling of nutrients through leaves, rhizomes and roots (Short et al., 2011). Recent reports have proved seagrass can also filter coastal water from pathogens that can reduce contamination in seafood and can reduce coral bacterial diseases (Cullen-Unsworth and Unsworth, 2018). Though seagrass ecosystems are valuable in terms of ecosystem functioning, they have not received international and social attention unlike other charismatic ecosystems, such as coral reefs and mangroves in terms of research, management and conservation practices (Nordlund et al., 2018). Globally 30\% of seagrass meadows have been lost in the last two-four decades (Murray et al., 2012; Howard et al., 2014) due to a combination of anthropogenic disturbances and global change scenarios and a further $30-40 \%$ loss is predicted to be lost in the next 100 years (Waycott et al., 2009; Pendleton et al., 2012). Short et al., (2011) provided valuable status of 67 seagrass species worldwide with extinction risk assessment and Halophila beccarii was one of the seagrasses that was on vulnerable list of International Union for Conservation of Nature (IUCN) in South-East Asia, including the coast of India. The loss of $H$. beccarii seagrass meadows are directly linked through habitat modification or indirectly linked to human induced disturbances (IUCN, 2010).

India and its vast extensive coastal ecosystems are part of South Asia (including other countries such as Pakistan, Sri-Lanka, Bangladesh and Maldives) and South-East Asia [due to Andaman and Nicobar Islands (ANI)] in the Indian Ocean region (Patro et al., 2017; Fortes et al., 2018). These diverse coastal ecosystems surrounding India consist of mangroves, coral reefs, salt marsh and seagrasses. While much of the attention has been towards mangroves and coral reefs, similar significant ecosystems such as seagrass are poorly understood (Jagtap, 1996; Patro et al., 2017). In India seagrass beds are declining due to human induced 
disturbances (Thangaradjou et al., 2009; Nobi et al., 2011; Kaladharan and Anasukoya, 2019; Mishra and Apte, 2020a) and lack of interest from scientific community on seagrasses has added to the foes (Jagtap et al., 2003; Mathews et al., 2010a; Patro et al., 2017; Bhatt and Patro, 2018).

The seagrass ecosystems of India consist of 16 out of 19 species found in South-east Asia, covering an area of $516.59 \mathrm{sq} \mathrm{Km}$ (Geevarghese et al, 2018) up to a depth limit of $21 \mathrm{~m}$ (Bayyana et al., 2020). Halophila beccarii Aschers. commonly known as 'Ocean Turf Grass' is distributed on both east and west coast of India (Parthasarathy et al., 1988; Jagtap, 1991; Jagtap et al., 2003) including the islands of Andaman and Nicobar (Savurirajan et al., 2015). Except the Indian coast, they also have a wide distribution in South-East Asia (Short et al., 2011) including their presence from the coast of Sri Lanka (Udagedra et al., 2017), Bangladesh (Abu Hena and Short, 2009; Masum Billah et al., 2016), Malaysia (Zakaria et al., 2002; Fakhrulddin et al., 2013), Philippines (Liao and Geraldino., 2020), Thailand (Aye et al., 2014; Hiranphan et al., 2020) and Viet Nam (Hang Phan et al., 2017). H. beccarii acts as one of the pioneer species in the ecological succession process leading to mangrove formation of the Indian coast (Jagtap, 1985; Untawale and Jagtap, 1991; Parthasarathy et al., 1988, 1991). The plant is tolerant to wide fluctuations in salinity, temperature and tidal fluctuations and requires high nutrient content (Untawale and Jagtap, 1981; Jagtap, 1991; Greve and Binzer, 2004; Fakhrulddin et al., 2013) for growth and production. However, H. beccarii is listed as Vulnerable category under the IUCN Red List (Short et al., 2011) and it has been found as endangered in Sri Lanka (Udagedra et al., 2017) and locally extinct in Philippines (Liao and Geraldino., 2020). This suggests the vulnerability of this small seagrass species is increasing around the Indian Ocean region. Saying that, there is a significant knowledge gap on $H$. beccarii research in India compared to other seagrass species like Thalassia hemprichii, 
Cymodocea serrulata, C. rotundata, Enhalus acoroides, Halophila ovalis, H. ovata and $H$. decipens.

Therefore, the objective of the proposed review is to collect various information of $H$. beccarii ecosystems from literature survey and derive the current knowledge gaps on $H$. beccarii research. We will use the DAPSIR model developed by Smith et al., (2016) to understand the effects of various drivers that have increased the Vulnerability of this seagrass around the coast of India and propose feasible management practices for better conservation and management of these seascapes. 


\section{Materials and Methods}

We searched various search engines including Scopus, Google Scholar, ISI Web of Knowledge, Science Direct, JSTOR and Research Gate with key words like Halophila beccarii, India, distribution, diversity, carbon sequestration, bioactive compounds, morphometrics and ecosystem services. Single words and a combination of two or more words were used on the various search engine platforms. Searches included all articles published until or cut-off date $27^{\text {th }}$ July 2020. Data was collected from peer reviewed, grey literature and various reports and were compiled and disseminated according to the category they fit in. We found a total of 187 research publications on seagrass ecosystems of India between the year 1977 to 2020 and identified further 38 relevant publications from the references of these articles. Then, we read through the full texts to sort out the relevant publications regarding to the ecology of Halophila beccarii. Other than ecology we also sorted out the articles related to various biochemical, physico-chemical, morphometrical, trace elements and ecosystem services articles. The units/values obtained from the articles related to various parameters collected from literature review were converted to similar units for better comparison. The data generated from literature survey was used with the DAPSIR conceptual framework (Smith et al., 2016; Elliott et al., 2017) to provide management and assessment issues for $H$. beccarii ecosystems of India. The DAPSIR framework uses a combination of Drivers-ActivitiesPressure-State-Impact and Response parameters to assess the impact of multiple threats and their cumulative impacts for better management of ecosystems by the local authorities (Griffiths et al., 2020). 


\section{Results and Discussion}

We found a total of 54 number of publications that was related to various studies of $H$. beccarii (Fig.1). H. beccarii studies comprised 9.5\% of the total seagrass research in India, while Cymodocea serrulata (11.6\%), Syringodium isoetifolium (11.3\%) and T. hemprichii $(10.5 \%)$ had higher number of studies respectively. The higher percentage of studies belonging to the above three seagrass species is directly related to their pan India distribution and presence of large meadows (Jagtap et al., 2003; Purvaja et al., 2008). A total of 54 (9.5\%) number of publications were found for $H$. beccarii, out of which 26 number of publications were based on individual $H$. beccarii studies, whereas 32 were part of mixed seagrass species. There were 10 out of 26 and five out 36 review articles, from both individual and mixed studies respectively. In the decade wise publications, the first record of seagrass research in India was based on $H$. beccarii before 1980s, thus consisting $100 \%$ (Fig.2). In the last four decades seagrass research in India has grown significantly, with $H$. beccarii consisting around a ca. of $25 \%$ of research publications. However, research publications on $H$. beccarii has decreased by 7\% after it was declared as Vulnerable by IUCN in 2011 (Fig.2). The various categories of studies on H. beccarii is presented in Fig. 3 and discussed below.

\subsection{Physico-chemical parameters}

The physico-chemical parameters of both east and west coast are different (Table 1). The depth limit for $H$. beccarii on the west coast was up to $1 \mathrm{~m}$, while that on the west coast was up to $1.7 \mathrm{~m}$. However, there were certain variables which were not reported from the west coast, such as water depth, photosynthetic active radiation and certain nutrients (Table1), but are reported from the east coast. This bias in data made it difficult to compare these variables with other seagrass ecosystems of India, reported by Thangaradjou et al., 2018. The salinity range (5-35) on the west coast (Untawale and Jagtap, 1977; Jagtap et al., 2003) is more 
fluctuating compared to that of east coast (Bharathi et al., 2014; Pati et al., 2014 and references there in). H. beccarii meadows of the west coast have 1.5-fold higher nitrate levels compared to the east coast (Table 1). This difference can be due to the presence of $H$. beccarii meadows alongside mangroves on the west coast, while that of east coast is mostly with seagrasses (Jagtap and Untawale, 1977; Jagtap et al., 2003). However, most of the environmental variables such as salinity and nitrate levels data from the west coast are more than three decades old and there is a significant need of new data collection from the $H$. beccarii meadows is necessary from the west coast. Interestingly, when compared with other seagrass meadows of India, the nutrient levels in $H$. beccarii meadows on each coast is comparatively lower (Table 1).

\subsection{Distribution of H. beccarii in India}

H. beccarii commonly called as Ocean Turf Grass, is a small submerged creeper that belongs to family Hydrocharitaceae and has a pan India distribution on the east coast and west coast including the islands of Andaman and Nicobar (Fig.3and 5). H. beccarii distribution comprises $29 \%$ of studies on both coast (Fig.4). The seagrass was first was recorded from Chilika lagoon, Odisha in the east coast (den Hartog 1971) and on the west coast by Untawale and Jagtap, (1977) at Mandovi Estuary, Goa. Untawale and Jagtap, (1981) proposed that the plant migrated to the west coast from other locations of west coast of Indian Ocean through a peculiar phenomenon of 'one jump migration', where the plant transports and establishes itself through plant fragmentation (Lipkin, 1972). Savurirajan et al., (2015) recorded this phenomenon at their study site of Hado bay in Andaman and Nicobar Islands of India, where a cyclone damaged site of $H$. beccarii was naturally restored from plant fragments from another site and Hang Phan et al., (2017) observed this phenomenon in the lagoon of Viet Nam. This short distance dispersal of $H$. beccarii plays a significant role in its migration and meadow maintenance and colonisation (Hang Phan et al., 2017). 
Through its distribution on both coast of India, H. beccarii has been found in shallow sandy and silty or muddy or clayey habitat within a depth limit from zero to $1 \mathrm{~m}$ on the west coast (Parthasarathy et al., 1988; Jagtap, 1991) and one to $1.7 \mathrm{~m}$ on the east coast ( Jagtap, 1996; Mathews et al., 2010), that is reflected through its presence near to mangrove zonation or mangrove mudflats. This association of $H$. beccarii was observed at Pichavaram mangrove area, Tamil Nadu on the east coast of India (Parthasarathy et al.,1988,1991; Bharathi et al., 2014) and the mangrove zones of Mandovi estuary, Goa (Untawale and Jagtap, 1977; Jagtap and Untawale, 1981; Jagtap, 1991), Shirgaon creek mangroves, Achra creek and Kolamb mangrove creek, Maharashtra (Jagtap, 1991, Apte et al., 2016), Kumbala and Kadalundi estuary, Karnataka (Kaladharan and Asokan, 2012) on the West coast of India (Fig.3 and 5). Though $H$. beccarii is mostly associated with mangrove areas, this seagrass was also found associated with other seagrasses such as Halophila ovata, Halophila ovalis, Halodule uninervis and Halodule pinifolia in Chilika lagoon, Odisha (Sahu et al., 2014; Pati et al., 2014), Pullicat lake, Andhra Pradesh (Vani et al., 2018), Palk bay and Gulf of Mannar, Tamil Nadu, (Ramamurthy, 1981; Raghavan and Deshpande, 1982; Parthasarathy et al., 1988, 1991), Puducherry coast (Kalimuthu et al., 1995) and Hado bay, Andaman and Nicobar Islands (Savurirajan et al., 2015) on the east coast of India (Fig.3). Other than mangroves and seagrass, H. beccarii was also found being associated with seaweeds, such as Hypnea valentia on the east coast (Parthasarathy et al., 1988; Kalimuthu et al., 1995) and Enteromorpha linza in Kadalundi estuary, west coast (Kaladharan and Asokan, 2012). This association with mangroves or seaweed (e.g. Ulva intestinalis) has also been observed from the coast of Bangladesh (Abu Hena and Short, 2009; Abu Hena et al., 2013) and Malaysia (Zakaria et al., 2002). Being present in the shallow intertidal region, the plant has developed adaptation mechanisms to avoid desiccation during low tides by utilizing the sediment pore water content 
and forming thin layer of water films on leaf surface, for which the presence of leaf hairs plays a significant role (Untawale and Jagtap, 1981; Jagtap, 1991).

\subsection{Morphometric traits}

The morphometric features of $H$. beccarii is the most studied variable, comprising $41 \%$ compared to other variables from India (Fig.4) even though there is difference in number of publications from both east and west coast of India (Table 1). Various morphometric features of $H$. beccarii is better represented from east coast of India compared to that of the west coast. However, certain morphometric features like presence of epidermal spines (7-12 nos.) are only reported from the west coast (Untawale and Jagtap, 1977) and other features like canopy height and productivity are reported only from east coast (Bharathi et al., 2014). Various morphometric features like leaf thickness, petiole thickness, internode diameter, root length and root diameter are reported for the first time by Savurirajan et al., (2015), when they first recorded $H$. beccarii from the Andaman and Nicobar Islands (Table 1). The number of leaves of $H$. beccarii and leaf length are almost similar between the both coasts. However, the leaf width on the west coast is 5-fold higher than of the east coast (Untawale and Jagtap, 1977; Kaladharan, 2004). Among the various morphometric features, shoot density, above-ground (AG) and below-ground (BG) biomass are most studied on the east coast. The average shoot density of $H$. beccarii on the east coast is around 9 to 37 -fold higher than that of the west coast. In general, we observed that AG biomass of $H$. beccarii was higher than BG biomass on the east coast, while there are no reports on BG biomass from the west coast. The AG-biomass of H. beccarii from the west coast was lower than that from the east coast. The general patten of higher AG than BG biomass has also been observed for $H$. beccarii around the coast of Bangladesh and Thailand respectively (Abu Hena et al., 2007; Aye et al., 2014). 


\subsection{Reproductive traits}

H. beccarii reproductive traits constitute $33 \%$ of publications recorded from both east and west coast comprising a total of three number of publications (Fig.4). In general, the reproductive features of the seagrasses of India has been less explored. We found that, $H$. beccarii has both sexual and asexual mode of replication on the Indian coast (Jagtap and Untawale, 1981; Parthasarathy et al., 1988, 1991) and from the coast of Bangladesh and Viet Nam (Zakaria et al., 2002; Hang Phan et al., 2017). Sexual reproduction plays an important role in maintaining the genetic diversity, while asexual reproduction through clonal propagation helps in maintaining the meadows (Zakaria et al., 2002; Hang Phan et al., 2017). $H$. beccarii is monoecious and the flowers are strongly protogynous, with male and female flowers occurring in successive lateral shoots (Parthasarathy et al., 1988). The flowering seasons of $H$. beccarii in India varies between the east and west coast. In the east coast both flowering and fruits were observed within $H$. beccarii population from Feb-April (Parthasarathy et al., 1988, 1991), whereas in the west coast flowering and fruits have been observed as late as October-November (Jagtap and Untawale, 1981; Kaladharan, 2004).

The flowering of $H$. beccarii is followed by formation of large fruits, in which the number of seeds vary from one to four (Parthasarathy et al., 1988; Kaladharan, 2004). The fruits of $H$. beccarii are ellipsoidal, trilocular, $3.5 \mathrm{~mm}$ length and $1.5 \mathrm{~mm}$ width (Parthasarathy et al., 1988; Kaladharan, 2004). However, these differences in flowering and fruiting on east and west coast of India, can be attributed to the onset of monsoon and associated salinity and temperature changes (Jagtap and Untawale, 1981; Parthasarathy et al., 1988; Jagtap et al., 2003). The effects of monsoon are correlated with large inputs of freshwater in the estuarine zone and reduction in salinity levels, which affects $H$. beccarii reproductive features (Jagtap, 1981). Reproductive traits of $H$. beccarii plays a significant role in short dispersal of the seeds (Hang Phan et al., 2017) and a better understanding of the effects of various habitat 
disturbances on reproductive traits of $H$. beccarii is essential from the coast of India for better management practices, which has been recently reported for other mangrove associated seagrass such as T. hemprichii from the coast of Andaman and Nicobar Islands (Mishra and Apte, 2020b).

These differences in the morphometric features and reproductive traits of $H$. beccarii on the east and west coast can be due to three factors, i) the number of studies that have reported the morphometric and reproductive traits from east coast are higher than that of the west coast resulting in higher or lower average values ii) the influence of habitat and environmental variables, as most of the distribution of $H$. beccarii on the west coast is being associated with mangroves where the habitat disturbance is higher resulting in lower morphometric values, where that on the east coast is mostly with other seagrasses and seaweeds with lower disturbances and iii) the influence of monsoon and its associated salinity, temperature changes and nutrients influx, which is higher on the west coast compared to the east coast. This explains the wider leaves $H$. beccarii on the west coast.

\subsection{Biochemical property and bioactive compounds}

A pan India study on use of seagrass in local cultures revealed that $H$. beccarii is generally not used in local ethnobotanical purposes (Newmaster et al., 2011) resulting in only $7 \%$ of all bioactive compounds studies in India. H. beccarii being small in size compared to other seagrasses like Enhalus acoroides and Syringodium isoetifolium and their presence in muddy habitats restricts access for use in local cultures (Newmaster et al., 2011). Secondly, the nutritional value of $H$. beccarii leaves $\left(29.16 \mathrm{~K} \mathrm{cal} \mathrm{g}^{-1}\right)$ are low with high tannin and phenol content that makes it non-edible without cooking (Pradheeba et al., 2011).However, this plant has immense potential in providing various bioactive compounds, which have been identified 
recently, with bioactive compounds as antidiabetic (Vani et al., 2018), anti-dengue fever treatment (Ali et al., 2012), antioxidants (Neelima et al., 2015; Kar et al., 2019) and against various human pathogens (Kavitha et al., 2020). Seagrasses like T. hemprichii that are also found associated with mangroves (Mishra and Apte, 2020a) have been found to be a good source of bioactive compounds (Mishra and Mohanraju, 2018).

\subsection{Ecological significance of $H$. beccarii}

H. beccarii being present in the upper intertidal zone supports a rich biodiversity of invertebrates, such as nematodes, polychaetes and molluscs (Ranjitham et al., 2008; Nedumaran and Manokaran, 2009; Mathews et al., 2010a). H. beccarii associated biodiversity studies represent $26 \%$ of the total seagrass studies in India. However, much of these studies are part of field surveys including other seagrasses. We found an interesting pattern of species association with $H$. beccarii, where the invertebrate species richness and abundance were higher during monsoon season (Nedumaran and Manokaran, 2009). This suggests that when other seagrass species (such as Halodule pinifolia and Halophila ovalis) have a decrease in biomass, density and associated species diversity, H. beccarii can invest in its productivity and increase its growth of morphometric features during monsoon due to high input of nutrients from land run-off (Jagtap, 1996; Jagtap et al., 2003; Mathews et al., 2010a; Manikandan et al., 2011a,c) that directly influences the shoreward migration of invertebrates to $H$. beccarii patches (Nedumaran and Manokaran, 2009; Mathews et al., 2010a). Other than serving as habitat for invertebrates, $H$. beccarii also serves as a nursery for various fish juveniles and acts as a food source for marine mega herbivores such as turtles and dugongs (Anand, 2012; Gamboj, 2012; Singh et al., 2004 and references therein).

$H$. beccarii being present at the land and sea interface possess higher bioindication potential to assess metal contamination of coastal ecosystem. However, in India there is only 
one research article from the west coast reporting about the trace metals $(\mathrm{Ca}, \mathrm{Cu}, \mathrm{Fe}, \mathrm{K}, \mathrm{Mg}$, Mn, Na, Ni, Sr and Li) concentration in H. beccarii (Jagtap, 1983). The various other ecosystem services of $H$. beccarii are presented in Table 3. There is a significant gap in ecosystem studies of $H$. beccarii population regarding their carbon sequestration potential as research on seagrass carbon sequestration capacity has been very limited in India (Ganguly et al., 2017), even though the potential of $H$. beccarii is very high. Similarly, there is little information on their primary productivity of $H$. beccarii in India (Ghevade and Joshi, 1980).

$H$. beccarii play an important role in coastal protection and sediment stabilization (Jagtap et al., 2003; Kaladharan et al., 2018), but more studies are required on this aspect to understand the various process involved in the coastal protection services. H. beccarii and its association with mangroves or seagrasses acts as ecological engineers to enhance the water quality and increase associated biodiversity of coastal ecosystems (Jagtap et al., 1983; Mathews et al., 2010a; Purvaja et al., 2018). This ecological connectivity between mangrove-seagrass has been recently reported from India (Mishra and Apte, 2020a; Mishra and Kumar, 2020c) and should be further explored using $H$. beccarii, as this seagrass forms climax communities that helps in establishing mangrove population. This ecological connectivity between $H$. beccarii-mangroves can be utilised for better management and restoration of both mangroves and seagrass ecosystems of India.

\subsection{H. beccarii Genetics}

Karyomorphological studies of $H$. beccarii indicated the presence of diploid $(2 \mathrm{n}=18)$ chromosomes (Vanitha et al., 2016), whereas genetic diversity and phylogeny of $H$. beccarii was carried out by Kar et al., (2018) indicating its polymorphic nature. However, both of these molecular studies have been carried out on $H$. beccarii from Tamil Nadu and Odisha on the east coast respectively. A more detailed study covering the sampling of this species from the 
entire coast of India is necessary to understand the genetic variation of $H$. beccarii, as local environmental variables determine both phenotypic plasticity and genetic response of seagrass (Nguyen et al., 2015; King et al., 2018). Supporting this evidence is a recent study on karyomorphological properties of $H$. beccarii from the coast of Thailand, that revealed in difference of $H$. beccarii karyomorphological properties from India and China (Hang Phan et al., 2017).

\subsection{Threat analysis using DAPSIR model}

Being present at the near interface of land and sea interaction with fragile muddy habitats, $H$. beccarii is prone to natural disasters and anthropogenic disturbances. Using the DAPSIR model, we found three main drivers, that have various Activities and Pressures associated with them which were interlinked and can have serious negative impacts on the $H$. beccarii population of India (Fig.6). The main threats (Drivers) to H. beccarii are through marine food provisioning and coastal urbanisation, which have various activities and pressures on the $H$. beccarii ecosystem. Both these drivers are based on various Activities, but we found that habitat disturbance consists a majority of the Activities, due to fishing, coastal development, sand dredging, boat anchoring, conversion of coastal habitats into salt pans and trampling due to tourism (Fig.6). These disturbances combined together mostly created multiple Pressure on the seagrass habitats and associated biodiversity, for example fishing (Activities) cause abrasion (Pressure) and that leads to habitat fragmentation and decrease in health and resilience of $H$. beccarii meadows (State Change). The various Activities and its associated Pressure and State Change are diagrammatically represented in Fig.6. However, the DAPSIR model suggests possible Response from management, which in case of $H$. beccarii is to reduce and minimize the effects of habitat disturbance. 
In India a significant loss has been detected for this species due to various coastal developmental activities, for example, $H$. beccarii was found to be present in the Pichavaram mangrove area when Parthasarathy et al., surveyed in 1988, but the same species was absent in 2014, when surveyed by Bharathi et al., (2014) as a result of increase in fishing activities. A fundamental issue in India about environmental management of coastal resources is uncertainty and lack of interest of the scientific community in seagrass ecosystems, when compared to coral reefs or mangroves (Jagtap, 1996; Purvaja et al., 2008; Ganguly et al., 2017). Other than the various anthropogenic activities, climate change as a stressor is going to induce changes in thermal and salinity regimes (Fig.6), which will directly impact the productivity of $H$. beccarii ecosystems of India. Other than these pressures, the east coast of India is constantly battered by tropical cyclones and the seagrass ecosystems suffer a lot, for example in the Chilika lagoon, Odisha are the most suffered ecosystem (Banerjee et al., 2018).

\section{Conservation and Management}

The loss of biodiversity under the influence of multiple stressors is pushing ecosystem boundaries and associated biodiversity towards mass extinction worldwide (Intergovernmental Science-Policy Platform on Biodiversity and Ecosystem Services, (IPBES), 2019) which emphasizes the importance of biodiversity conservation from anthropogenic disturbances and climate change scenarios. $H$. beccarii as a seagrass ecosystem has potential for climate change mitigation through carbon sequestration and storage capacity (Macreadie et al., 2019; Serrano et al., 2020). Secondly, it can provide refugee to various calcifying organisms from ocean acidification (Bergstorm et al., 2019). Most importantly its ecological connectivity with mangroves can influence resilience and adaptation to various climate change scenarios (Gillis et al., 2017). These features of seagrass ecosystem along with 24 different types of ecosystem services places seagrass as the third most important ecosystem in the world (Nordlund et al., 
2016), which has called for better conservation and management of seagrass ecosystems worldwide (UNEP, 2020).

However, for $H$. beccarii the importance of conservation and management is more significant due to the Vulnerability of its population. Lack of population trends data in India on $H$. beccarii should be addressed. The seagrass research community of India has to come out of their shells to work collectively and collaborate with various regional research centres for better monitoring of $H$. beccarii ecosystems of India. This lack of interest is reflected over the last four decades of seagrass research in India, with more than $73.8 \%$ of seagrass publications in India is from Palk bay and Gulf of Mannar in the state of Tamil Nadu, even though seagrass ecosystems distribution is diverse (Fig.3). This lack of interest for seagrass research has been highlighted by various authors (Jagtap et al., 2003; Mathews et al., 2010a; Thangaradjou and Bhatt, 2018).

However, for better management of $H$. beccarii ecosystem of India, there is a need of better integration of research and policy (Ramesh et al., 2018; Koshy et al., 2018). The DAPSIR model indicated better management practices of $H$. beccarii ecosystems are needed for reducing the impacts of various anthropogenic and climate change impacts. Though India has a National Environmental Policy (NEP, 2006) of the Government of India, it does not highlight the importance of seagrass ecosystems of India. However, the National Policy on Marine Fisheries (NPMF, 2017) clearly emphasizes the importance of seagrass ecosystems and its protection from anthropogenic impacts. Recently, the Ministry of Environment Forest and Climate Change of the Government of India has proposed an An Inventory of Seagrass and Seagrass Ecosystems of India (Koshy et al., 2018). This inventory proposed a series of guidelines to highlight the importance of seagrass ecosystems in India along with the valuation of their ecosystem services and long-term monitoring. These various initiatives need to be implemented properly and long-term research on $H$. beccarii from both east and west coast of 
India is the need of the hour. Saying that, the critical knowledge gaps on $H$. beccarii research in India include

- Lack of $H$. beccarii population trends such as growth rate, productivity, recruitment and mortality rate

- Lack of scientific research on impact of multiple stressors (various anthropogenic pollutants and habitat disturbances) on $H$. beccarii eco-physiological functions

- Impact of ocean acidification on the population structure and carbon sequestration capacity of $H$. beccarii meadows

- Facilitative interactions between bivalves and $H$. beccarii ecosystems that reduce sulfide toxicity and maintains seagrass growth

- Effect of global warming and sea-surface temperature increase on $H$. beccarii photophysiology

- Role of $H$. beccarii in carbon sequestration and storage and its economic gains

- Monitoring of $H$. beccarii meadows across the coastal seascape as coral reefs or mangroves

- Understanding the role of ecological connectivity between $H$. beccarii and mangroves in maintaining commercial fisheries

- Quantifying the economic values of various ecosystem services of $H$. beccarii ecosystems

- Understanding the genetic diversity and molecular adaptation to various stressors is important to decode the resilience of $H$. beccarii to multiple stressors

\section{Acknowledgement:}

We are thankful to M. Maithreyi for her help in editing the manuscript. 


\section{References:}

Abu Hena, M.K., and Short, F., 2009. A new record of seagrass Halophila beccarii Ascherson in Bangladesh. CMU. J. Nat. Sci. 8, 201-206

Abu Hena, M.K., Sidik, J., Aysha, A., Ahsan, H., Short, F.D. Estuarine macrophytes at Bakkhali, Cox's Bazar, Bangladesh with reference to Mangrove diversity. Chiang Mai J. Sci. 40, 556-563

Ali, M.S., Ravikumar, S., Beula, J.M., 2012. Bioactivity of seagrass against the dengue fever mosquito Aedes aegypti larvae. Asian Pacific J. Trop. Biomed.2, 570-573

Apte, D.A., Bhave, V., Bhave, A., Nagale, P., Pitale, R., 2016. Ecologically important marine and coastal biodiversity areas of Maharashtra, India. Bombay Natural History Society, Pp.36

Banerjee, K., Paneerselvam, A., Ramachandran, P., Ganguly, D., Singh, G., Ramesh, R., 2018. Seagrass and macrophyte mediated $\mathrm{CO}_{2}$ and $\mathrm{CH}_{4}$ dynamics in shallow coastal waters. PLoS ONE. 13,1-22

Bergstrom, E., Silva, J., Martins, C., Horta, P., 2019. Seagrass can mitigate negative ocean acidification effects on calcifying algae. Sci. Rep. 9, 1-11

Bhatta, K., Patra, H.K., 2018. Spatial and temporal distribution of seagrasses in Chilika Lagoon. Int. J. Innov. Res. Tech. 4, 415-418

Bharathi, K., Subhashini, P., Raja, S., Ranith, R., Vanitha, K., Thangaradjou, T., 2014. Spatial variability in distribution of seagrasses along the Tamilnadu coast. Int. J. Curr. Res. 6, 8997-9005

Björk, M., Short, F., Mcleod, E. \& Beer, S. (2008). Managing seagrasses for resilience to climate change. IUCN. Gland, Switzerland, $56 \mathrm{pp}$.

Constanza, R., de Groot, R., Sutton, P., van der Ploeg, S., et al., 2014. Changes in the global value of ecosystem services. Global Environ. Change. 26:152-158.

Cullen-Unsworth, L.C., Jones, B.L., Lilley, R., Unsworth, R.K.F., 2018. Secret gardens under the sea: what are seagrass meadows and why are they important? Frontiers for Young Minds. 6,1-10

Cullen-Unsworth, L.C., and Unsworth, R., 2018. A call for seagrass protection. Science. $361,446-448$

Dilipan, E., Papenbrock, J., Thangaradjou, T., 2017a. Random amplified polymorphic DNA (RAPD) finger prints evidencing high genetic variability among marine angiosperms of India. J. Mar. Biolog. Assoc., UK. 97, 1307-1315

Duarte, C. M., J. J. Middelburg, and N. Caraco (2005), Major role of marine vegetation on the oceanic carbon cycle, Biogeosciences, 2,1-8

Duarte, C.M., Kennedy, H., Marba, N., Hendriks, I., 2013. Assessing the capacity of seagrass meadows for carbon burial: current limitations and future strategies. Ocean Coast. Manage. 82,32-38 
Duke, N.C., Meynecke, J.O., Dittmann, S., Ellison, A.M., Anger, K., et al., 2007. A world without mangroves? Science. 317, 41-42

Elliott, M., Burdon, D., Atkins, J.P., Borja, A., Cormier, R., de Jonge, V.N., Turner, R.K., 2017. "And DPSIR begat DAPSI(W)R(M)!" - a unifying framework for marine environmental management. Mar. Pollut. Bull. 118, 27-40.

Fakhrulddin, I.M., Sidik, B.J., Harah, M., 2013. Halophila beccarii Aschers (Hydrocharitaceae) responses to different salinity gradient. J. Fish. Aquat. Sci. 8, 462-471

Fortes, M.D., Ooi, J.L.S., Tan, Y.M., Prathep, A., Bujang, J.S., Yaakub, S.M., 2018. Seagrass in Southeast Asia: A review of status and knowledge gaps and a road map for conservation. Bot. Mar. 61, 269-288

Ganguly, D., Singh, G., Purvaja, R., Bhatta, R., Paneer Selvam, A., Banerjee, K., Ramesh, R., 2017. Valuing the carbon sequestration regulation service by seagrass ecosystems of Palk Bay and Chilika, India. Ocean Coast. Manage. 159, 26-33

Geevarghese, G.A., Akhil, B., Magesh, G., Krishnan, P., Purvaja, P., Ramesh, R., 2018. A comprehensive geospatial assessment of seagrass distribution in India. Ocean Coast. Manage. 159, 16-25

Ghevade, K.S., Joshi, G.V., 1980. Photosynthetic and photorespiratory carbon metabolism in the seagrass Halophila beccarii (Aschers). Indian J. Exp. Biol. 18, 1344-1345.

Gillis, L.G., Jones, C.G., Ziegler, A.D., van der Wal, D., Breckwoldt, A., Bouma, T.J., 2017. Opportunities for Protecting and restoring tropical coastal ecosystems by utilizing a physical connectivity approach. Front. Mar. Sci. 4, 374

Greve, T.M. and Binzer, T. 2004. Which factors regulate seagrass growth and distribution? In: Borum, J., Duarte, C.M., Jensen D.K. and Greve, T.M. (eds.), European seagrasses: an introduction to monitoring and management. pp. 19-23

Green, E.P. \& Short, F. (2003). World Atlas of Seagrasses. UNEP World Conservation Monitoring Centre. Berkeley: University of California Press

Griffiths, L.L., Conolly, R.M., Brown, C.J., 2020. Critical gaps in seagrass protection reveal the need to address multiple pressures and cumulative impacts. Ocean Coast. Manage.183, 104946

Guannel, G., Arkema, K., Ruggiero, P., Verutes, G., 2016. The Power of three: Coral reefs, seagrasses and Mangroves protect coastal regions and increase their resilience. PLoS ONE. $10: 1-22$.

Hang Phan, T.T., De Raeymaeker, M., Quang, D.L., Triest, L., 2017. Clonal and genetic diversity of the threatened seagrass Halophila beccarii in a tropical lagoon: Resilience through short distance dispersal. Aquat. Bot. 142, 96-104 
Heck, K. L., Carruthers, T. J. B., Duarte, C. M., Hughes, A. R., Kendrick, G., Orth, R. J., \& Williams, S. W. (2008). Trophic transfers from seagrass meadows subsidize diverse marine and terrestrial consumers. Ecosystems, 11, 1198-1210.

Hemminga, M.A. and C.M. Duarte. 2000. Seagrass ecology. Cambridge University Press, New York. 298 pp.

Hiranphan, R., Hiranphan, P., Puangpairote, T., Prathep, A., Eksomtramage, L., Karyomorphology of Three Halophila species ( Hydrocharita- ceae, Alismatales ) from Haad Chao Mai National Park, Trang Province, Thailand. Chiang Mai J. Sci. 2020. 47, 57 63

Howard, J., Hoyt, S., Isensee, K., Telszewski, M., Pidgeon, E., (eds.) (2014). Coastal blue Carbon: Methods for assessing carbon stocks and emissions factors in mangroves, tidal salt marshes, and seagrasses. Conservation International, Intergovernmental Oceanographic Commission of UNESCO, International Union for Conservation of Nature. Arlington, Virginia, USA

IUCN, 2010. http://www.iucnredlist.org/details/173319/0, Accessed date: 28 February 2020 .

Jagtap, T.G., and Untawale, A.G., 1981. Ecology of seagrass bed of Halophila beccarii Aschers. In Mandovi Estuary, Goa. I. J. Geo-Mar. Sci. 10, 402-404

Jagtap, T.G., 1983. Metal distribution in Halophila beccarii (Aschers) and surrounding environment along the central west coast of India. Mahasagar 16 (4), 429-434

Jagtap, T.G., 1991. Distribution of seagrasses along the Indian coast. Aquat. Bot. 40, 379386

Jagtap, T.G., 1996. Some quantitative aspects of structural components of seagrass meadows from the southeast coast of India. Bot. Mar. 39, 39-45.

Jagtap, T.G., Komarpant, D.S. \& Rodrigues, R.S. Wetlands (2003) 23: 161. https://doi.org/10.1672/0277-5212

Kamboj, R.D., 2012. Biology and status of seagrasses in Gulf of Kachchh Marine National Park and Sanctuary, India. Indian Ocean Turtle Newsletter. 19, 8-11

Kaladharan, P., 2006. Occurrence of Halophila beccarii Asch from Kumbala estuary, Kerala. J. BNHS. 103, 137-138

Kaladharan, P., Zacharia, P.U., Vijayakumaran, K., 2011. Coastal and marine floral biodiversity along the Karnataka coast. J. Mar. Biolog. Assoc. India. 53, 121-129

Kaladharan, P., and Asokan, P.K., 2012. Dense bed of seagrass Halophila beccarii in Kadalundi Estuary. Marine Fisheries Information Services. T \&E series. 208, 33-34

Kaladharan, P., 2012. Vulnerable threatened marine ecosystems of India. CMFRI Bulletin.1-8 
Kaladharan, P., Ramya, A., Anasukoya, A., 2018. Seagrass meadows in India and their certain ecosystem services. Discovery Nature. 12, 108-114

Kalimuthu, S., Kaliaperumal, N., Ramalingam, J.R., 1995. Distribution of algae and seagrasses in the estuaries and backwaters of Tamil Nadu and Pondicherry. Seaweed Res. Utilin. 17, 79-86

Kannan, L.T., Thangaradjou, T., Anantharaman, P., 1999. Status of seagrasses of India. Seaweed Res. Utilin. 21, 25-33

Kar, S.K., Tripathy, P.K., Naik, S.K., Panda, P.C., 2018. Assessment of genetic diversity and phylogeny of the seagrasses of Odisha coast using molecular markers. Plant Sci. Res.. 40, 37-46

Kar, S.K., Sahoo, S., Kar, B., Naik, S.K., Panda, P.C., 2019. Antioxidant Activity of Halophila Ovalis and Halophila Beccarii (Hydrocharitaceae): Two Important Seagrass Species of Chilika Lagoon, India. Asian J. Pharma. Clinical Res. 12, 136-140

Kathiresan K, \&Alikunhi NM (2011) Tropical coastal ecosystems: Rarely Explored for their interaction! Ecologia. 1: 1-22

King, N.G., McKeown, N.J., Smale, D.A., Moore, P.J., 2018. The importance of phenotypic plasticity and local adaptation in driving intraspecific variability in thermal niches of marine macrophytes. Ecography. 41, 1469-1484

Kavitha, D., Kalaivani, P., Vanitha, V., 2020. A review on phytochemicals and biological activities of seagrass. J Critical Rev. 7, 257-264

Koshy, N.E., Bhatt, J.R., Vakily, J.M., 2018. Synthesis of the conference on Management and Conservation of Seagrass Ecosystems in India. Ocean Coast. Manage. 159, 3-6

Lewis, M.A., \& Devereux, R., 2009. Non-nutrient anthropogenic chemicals in seagrass ecosystems: fate and effects. Environ. Toxicol. Chem. 28,644-661

Liao, L.M., Geraldino, P.J.L., 2020. Has Halophila beccarii Ascherson been locally extirpated in Philippines? Trop. Nat. Hist. 20, 104-110

Lucas C, Thangaradjou T, Papenbrock J., 2012. Development of a DNA Barcoding System for Seagrasses: Successful but Not Simple. PLoS ONE 7(1): e29987.

McLeod, E., Chmura, G.L., Bouillon, S., Salm, R., Björk, M., Duarte, C.M. et al. 2011. A blueprint for blue carbon: toward an improved understanding of the role of vegetated coastal habitats in sequestering $\mathrm{CO}_{2}$. Front. Ecol. Environ. 9, 552-560

Macreadie, P.I., Anton, A., Raven, J.A., Beaumont, N., Connolly, R.M., 2019. The future of Blue Carbon Science. Nature Communications. 10, 1-13

Manikandan, S., Ganesapandian, S., Singh, M., Kumaraguru, A.K., 2011a. Seagrass diversity and associated flora and fauna in the coral reef ecosystem of the Gulf of Mannar, Southeast Coast of India. Res. J. Environ Earth Sci. 3, 321-326

Manikandan, S., Ganesapandian, S., Parthiban, K., 2011b. Distribution and zonation of seagrasses in the Palk Bay, south-eastern India. J. Fish. Aquat. Sci. 6,178-185 
Manikandan, S., Ganesapandian, S., Singh, M., Kumaraguru, A.K., 2011c.Distribution and spatial variation of seagrass in the Northern Part of Gulf of Mannar, Southeastern India. Asian J Plant Sci. 10, 80-85

Mathews, G., Raj, D., Thinesh, T., Patterson, J., Edward, J.K.P., Wilhelmsson, D., 2010a. Status of seagrass diversity, distribution and abundance in Gulf of Mannar Marine National Park and Palk Bay (Pamban to Thondi) South eastern India. South Indian Coastal and Marine Bulletin. 2, 1-21

Meeran, M., Jailani, A.K., Dhinamala, K., Raveen, R., Arivoli, S., Tennyson, S., 2018. Molluscan biodiversity (phytal fauna) of Thondi coast in Palk Bay, Southeast coast of India. International Journal of Zoology Studies. 3, 145-153

Mishra, A.K., Mohanraju, R., 2018. Epiphytic bacterial communities in seagrass meadows of oligotrophic waters of Andaman Sea. OALib. J.5: 1-12.

Mishra, A.K., and Apte, D., 2020a. Ecological connectivity with mangroves influences tropical seagrass population longevity and meadow traits within an island ecosystem. Mar. Ecol. Prog. Ser. 644, 47-63.

Mishra, A.K., Apte, D., 2020b. Reproductive effort of intertidal tropical seagrass as indicator of coastal disturbance. doi: https://doi.org/10.1101/2020.07.19.177899

Mishra, A.K., Kumar, M., 2020c. Mangrove sediments act as source of nutrients and sink of heavy metals of coastal Andaman Sea. Indian J. Geo-Mar. Sci. 49, 156-166

Murray, N.J., Phinn, S.R., Clemens, R.S., Roelfsema, C.M. \& Fuller, R.A. 2012. Continental scale mapping of tidal flats across East Asia using the landsat archive. Remote Sensing, 4, 3417-3426.

Nair, V. 2002. Status of Flora and Fauna of Gulf of Kachchh. National Institute of Oceanography, Goa.157pp. http://drs.nio.org/drs/handle/2264/87

Nedumaran, N., Manokaran, S., 2009. Seasonal variations and distribution of sea grass associated macrofauna in Uppanar estuary, southeast coast of India. J. Phytol. 1, 172-176

Neelima, C., Sarika, S., Seenivasan, R., 2015. DPPH radical scavenging of selected seagrasses from South East Coast of India. Int. J. Adv Res. 3, 950-956

Newmaster, A.F., Berg, K.J., Ragupathy, S., Palanisamy, M., Sambandan, K., Newmaster, S.G., 2011. Local knowledge and conservation of seagrasses in the Tamil Nadu state of India. J. Ethnobiol. Ethnomed. 7, 37-54

Nguyen, V.X., Detcharoen, M., Tuntiprapas, P., Soe-Htun, U., Sidik, J.B., et al., 2014. Genetic species identification and population structure of Halophila (Hydrocharitaceae) from the Western Pacific to the Eastern Indian Ocean. BMC Evol. Biol. 14, 1-18

Nobi, E.P., 1993. Seagrasses the oxygen pumps in the sea. In: The wealth of India. Extension Bulletin of CSIR, National Institute of Science Communication, New Delhi.

Nordlund LM, Koch EW, Barbier EB, Creed JC (2016) Seagrass ecosystem services and their variability across genera and geographical regions. PLoS ONE. 10: e0163091.

Nordlund LM, Unsworth RK, Gullström M, Cullen-Unsworth LC (2017) Global 
significance of seagrass fishery activity. Fish Fisheries. 19:1-14

Nordlund LM, Jackson, EL, Nakaoka, M, Samper-Villarreal J, Beca-Carretero P, Creed JC (2018) Seagrass ecosystem services-What's next? Mar. Pollut. Bull. 134: 145-151

Ondiviela B, Losada I J, Lara JL, Maza M, Galvan C, Bouma TJ, Belzen J (2014) The role of seagrasses in coastal protection in a changing climate. Coastal Eng. 87:158-168

Orth, R.J., Carruthers, T.J.B., Dennison, W.C., Duarte, C.M., Fourqurean, J.W., et al., 2006. A global crisis for seagrass ecosystems. Bio. Science. 56, 987-996

Panda S, Bhatta KS, Rath KC, Mishra CR, Samal RN. Atlas of Chilika, Chilika Development Authority, Bhubaneswar, 2008; pp 133.

Pattanaik AK, Samal RN. Distribution, abundance and seasonality of seagrass meadows in Chilika Lagoon and its influence on the Lagoon ecosystem. Management and Conservation of Seagrass Eco- system in India Abstract 4. 2, 2016

Patro, S., Krishnan, P., Samuel, V.D., Purvaja, R., Ramesh, R., 2017. Seagrass and saltmarsh ecosystems in South Asia: An overview of Diversity, Distribution, Threats and Conservation. In Wetland Science: Perspectives from South Asia. pp 1-587

Parthasarathy, N., Ravikumar, K., Ramamurthy, K., 1988. Floral biology and ecology of Halophila beccarii Aschers. (Hydrocharitaceae). Aquat. Bot. 31, 141-151

Parthasarathy, N., Ravikumar, K., Ganesan, R., Ramamurthy, K., 1991. Distribution of seagrasses along the coast of Tamil Nadu, Southern India. Aquat. Bot. 40, 145-153

Pati, M.P., Lakshman, N., Das, S.S., Jagmohan, S., Behera, D.P., 2014. Studies on seagrasses in relation to some environmental variables from Chilika lagoon, Odisha, India. Int. Res. J Environ. Sci. 3, 92-101

Pendleton L, Donata MC, Murray BC, Crooks S, Jenkins WA, Sifleet S, Craft C, Fourqurean JW, Kauffman JB, Marbà N, Megonigal P, Pidgeon E, Herr D, Gordon D, Baldera A (2012) Estimating global "Blue Carbon" emissions from conversion and degradation of vegetated coastal ecosystems. PLoS ONE. 7: e43542

Pradheeba, M., Dilipan, E., Nobi, E.P., Thangaradjou, T., Sivakumar, K., 2011. Evaluation of seagrasses for their nutritional value. Indian J Geo-Mar. Sci. 40, 105-111

Purvaja, R., Ramesh, R., Shalini, A., Rixen, T., 2008. Biogeochemistry of Nitrogen in Seagrass and Oceanic systems. Memoir Geological Society of India. 73, 435-460

Purvaja, R., Robin, R.S., Ganguly, D., Hariharan, G., Singh, G., Raghuraman, R., Ramesh, R., 2018. Seagrass meadows as proxy for assessment of ecosystem health. Ocean Coast. Manage. 159, 34-45

Raghavan, R.S., and Deshpande, U.R., 1982. On the occurrence of Halophila beccarii Aschers (Hydrocharitaceae) in India. Bulletin of Botanical Survey of India. 24, 200-201 
Ramamurthy, K., 1981. Observations on the vegetation of South Arcot District, Tamil Nadu. Bulletin of Botanical Survey of India. 23, 107-109

Ramesh, R., Banerjee, K., Paneerselvam, A., Lakshmi, A., Krishnan, P., Purvaja, R., 2018. Legislation and policy options for conservation and management of seagrass ecosystems in India. Ocean Coast. Manage. 159, 46-50

Ranjitham, N.S., Thirumaran, G., Anantharaman, P., Nightingale, V.D.R., Balasubramanian, R., 2008. Associated Fauna of Seaweeds and Seagrasses in Vellar Estuary. American-Eurasian J. Bot. 1, 9-16

Rodrigues, J.G., Conides, A.J., Rodriguez, S.R., Raicevich, S., Pita, P., et al., 2017. Marine and Coastal cultural ecosystem services: knowledge gaps and research priorities. One Ecosystem. 2:e12290.

Sahu, B.K., Pati, P., Panigrahy, R.C., 2014. Environmental conditions of Chilika Lake during pre and post hydrological intervention: an overview. J Coast. Conserv. 18,285-297.

Savurirajan, M., Lakra, R.K., Ganesh, T., 2015. A new record of the seagrass Halophila beccarii Ascherson from the Port Blair coast, Andaman and Nicobar Islands, India. Bot. Mar. 58, 409-413

Savurirajan, M., Equbal, J., Lakra, R. K., Satyam, K., \& Thiruchitrambalam, G. ,2018a. Species diversity and distribution of seagrasses from the South Andaman, Andaman and Nicobar Islands, India. Bot. Mar. 61, 225-234.

Serrano, O., Lavery, P.S., Bongiovanni, J., Duarte, C.M., 2020. Impact of seagrass establishment, industrialization and coastal infrastructure on seagrass biogeochemical sinks. Mar. Environ. Res. 160, 104900

Short, F.T., Polidoro, B., Livingstone, S.R., Carpenter, K.E, et al., 2011. Extinction risk assessment of the world's seagrass species. Biol. Conserv.7,1961-1971.

Smith, C.J., Papadopoulou, K.N., Barnard, S., Mazik, K., Elliott, M., et al., 2016. Managing the marine environment conceptual models and assessment considerations for the European Marine Strategy Framework Directive. Front. Mar. Sci.

Sridhar, R., Thangaradjou, T., Kannan, L., 2008. Comparative investigation on physicochemical properties of the coral reef and seagrass ecosystems of the Palk Bay. Indian J. Mar. Sci. 37, 207-213

Thangaradjou, T., Kannan, L., 2005. Marine sediment texture and distribution of seagrasses in the Gulf of Mannar Biosphere Reserve. Seaweed Res. Utilin. 27, 145-154

Thangaradjou, T., Nobi, E.P., Dilipan, E., Sivakumar, K., Kannan, L., 2009. Seagrass under threat. Seagrass Watch. 39, 20-21.

Thangaradjou, T., Bhatt, J.R., 2018. Status of seagrass ecosystems in India. Ocean Coast. Manage. 159,7-15

Singh, H.S., C.N. Pandey, P. Yennawar, R.J. Asari, B.H. Patel, K. Tatu \& B.R. Raval. 2004. The marine national park and sanctuary in the Gulf of Kachchh - a comprehensive study on biodiversity and management issues. GEER Foundation, Gandhinagar 
Udagedara, S., Fernando, D., Perera, N., Tanna, A., Bown, R., 2017. A first record of Halodule pinifolia Miki den Hartog, and new locality of nationally endangered Halophila beccarii Asch , from the eastern coast of Sri Lanka. Int. J. Aquat. Biol. 5, 328-335

United Nations Environment Programme, UNEP, 2020. Out of the Blue: The value of seagrasses to the environment and to people. UNEP, Nairobi

Unsworth, R.K.F., Cullen, L.C., Pretty, J.N., Smith, D.J. \& Bell, J.J. (2010). Economic and subsistence values of the standing stocks of seagrass fisheries: Potential benefits of nofishing marine protected area management. Ocean Coast. Manage. 53, 218-224.

Umamaheswari, R., Ramachandran, S., Nobi, E.K., 2009b. Mapping the extend of seagrass meadows of Gulf of Mannar Biosphere Reserve, India using IRS ID satellite imagery. Int. J. Biodiv. Conserv. 1, 187-193

Untawale, A.G., and Jagtap, T.G., 1977. A new record of Halophila beccarii Aschers from Indian coast. Mahasagar Bulletin of National Institute of Oceanography., 10, 91-94

Vani, M., Vasati, T., Devi, U.M.P., 2018. Evaluation of in Vitro antidiabetic activity of methanolic extract of seagrass Halophila beccarii. Asian J. Pharma. Clinical Res.11, 150153

Vanitha, K., Subhashini, Pon, Thangaradjou, T., 2016. Karyomorphometric analysis of somatic chromosomes of selected seagrasses of families Hydrocharitaceae and Cymodoceaceae. Aquat. Bot. 133 (2016), 45-49

Waycott M, Duarte CM, Carruthers TJB, Orth RJ, Dennison WC, Olyarnik S, Calladine A, Fourqurean JW, Heck Jr, KL, Hughes AR, Kendrick GA, Kenworthy WJ, Short FT, Williams SL (2009) Accelerating loss of seagrasses across the globe threatens coastal ecosystems. PNAS. 106:12377-12381.

Zakaria, M.H., Bujang, J.S., Arshad, A., 2002. Flowering, fruiting and seedling of annual Halophila beccarii Aschers in Peninsular Malaysia. Bull. Mar. Sci. 71, 1199-1205 
1 Table.1 Range of various environmental variables recorded for $H$. beccarii from the west and 2 east coast of India and compared with other seagrass ecosystems reported by Thangaradjou et 3 al., (2018). Photosynthetic active radiation (PAR). No record (nr)

\begin{tabular}{llllll}
\hline $\begin{array}{l}\text { Environmental } \\
\text { variables }\end{array}$ & Range & & References & $\begin{array}{l}\text { Thangaradjou } \\
\text { et al., 2018 }\end{array}$ \\
\hline Depth & West coast & East coast & West coast & East coast & $0-15$ \\
\cline { 2 - 5 } Water pH & $0-1$ & $1-7$ & $\mathrm{k}$ & $\mathrm{d}$ & \\
Water temperature & $12.2-38.9$ & $27.10-33.2$ & $\mathrm{~d}$ & $\mathrm{a}, \mathrm{b}, \mathrm{c}, \mathrm{e}, \mathrm{f}$ & $6-8.9$ \\
$\left({ }^{\circ} \mathrm{C}\right)$ & $\mathrm{nr}$ & $7.49-8.35$ & & $\mathrm{a}, \mathrm{e}, \mathrm{f}$ & $24-34.5$ \\
Salinity & $5-35$ & $26.32-30.06$ & $\mathrm{i}, \mathrm{j}$ & $\mathrm{a}, \mathrm{b}, \mathrm{c}, \mathrm{e}, \mathrm{f}, \quad 18.32-39.4$ \\
PAR $(\mathrm{LUX})$ & $\mathrm{nr}$ & $900-1100$ & $\mathrm{nr}$ & $\mathrm{a}$ & $280-1440$ \\
Nitrate $(\mu \mathrm{M})$ & 7.2 & $0.55-4.09$ & $\mathrm{~h}$ & $\mathrm{a}, \mathrm{e}, \mathrm{f}$ & $0.25-19.2$ \\
Nitrite $(\mu \mathrm{M})$ & $\mathrm{nr}$ & $0.88-3.04$ & $\mathrm{nr}$ & $\mathrm{a}, \mathrm{e}, \mathrm{f}$ & $0.03-7.32$ \\
Phosphate $(\mu \mathrm{M})$ & $\mathrm{nr}$ & $0.98-4.32$ & $\mathrm{nr}$ & $\mathrm{a}, \mathrm{e}, \mathrm{f}$ & $0.12-7.32$ \\
Silicate $(\mu \mathrm{M})$ & $\mathrm{nr}$ & $3.29-8.99$ & $\mathrm{nr}$ & $\mathrm{a}, \mathrm{e}, \mathrm{f}$ & $0.6-18.99$ \\
\hline
\end{tabular}

4 a) Bharathi et al., 2014; b) Pati et al., 2014; c) Nedumaran and Manokaran, 2009; d) Jagtap, 5 1996; e) Sridhar et al., 2008; f) Sridhar et al., 2009; g) Jagtap, 1991; h) Jagtap and Untawale, 6 1981; i) Untawale and Jagtap, 1977; j) Jagtap et al., 2003; k) Mathews et al., 2010a 
8 Table 2. Morphometric variables, biochemical properties, of $H$. beccarii recorded from the 9 coast of India. Dry weight (DW), Carbon (C), Not recorded (nr), Carbon (C): Nitrogen (N), 10 Above ground $(\mathrm{AB})$, Below ground $(\mathrm{BG})$

\begin{tabular}{|c|c|c|c|c|}
\hline Variables & Range & & References & \\
\hline a. Morphometrics & West coast & East coast & West coast & East coast \\
\hline No. of leaves & $3-10$ & $4.66-9.33$ & $\mathrm{~d}$ & $a, b, c$ \\
\hline Leaf length (cm) & $1-1.07$ & $0.48-1.17$ & $\mathrm{~d}, \mathrm{e}$ & $a, b$ \\
\hline Leaf width (mm) & $1.5-20$ & $0.91-3.44$ & $\mathrm{~d}, \mathrm{e}$ & $a, b$ \\
\hline Leaf thickness (mm) & $\mathrm{nr}$ & $0.05-0.13$ & & $\mathrm{a}$ \\
\hline Epidermal spines (no.) & $7-12$ & $\mathrm{nr}$ & $\mathrm{d}$ & - \\
\hline Canopy height $(\mathrm{cm})$ & $\mathrm{nr}$ & 4.5 & - & $\mathrm{f}$ \\
\hline Petiole length (mm) & $7-14$ & $8.57-13.85$ & $\mathrm{~d}, \mathrm{e}$ & $a, b, c$ \\
\hline Petiole thickness (mm) & $\mathrm{nr}$ & $0.06-0.28$ & - & $\mathrm{a}$ \\
\hline Internode length (mm) & $\mathrm{nr}$ & $9.11-29.27$ & - & $a, b$ \\
\hline Internode diameter (mm) & $\mathrm{nr}$ & $0.33-0.68$ & - & $\mathrm{a}$ \\
\hline Rhizome diameter (mm) & $\mathrm{nr}$ & $0.39-0.65$ & - & $a, b$ \\
\hline Root length (mm) & $\mathrm{nr}$ & $9.25-33$ & - & $\mathrm{a}$ \\
\hline Root diameter (mm) & $\mathrm{nr}$ & $0.07-0.22$ & - & $\mathrm{a}$ \\
\hline Shoot density (no. $\mathrm{m}^{-2}$ ) & 420 & $3917-15707$ & 1 & $\mathrm{a}, \mathrm{c}, \mathrm{g}, \mathrm{h}, \mathrm{i}, \mathrm{j}, \mathrm{k}$ \\
\hline AG Biomass (g DW m ${ }^{-2}$ ) & 26.44 & $19.4-41.01$ & $\mathrm{~m}$ & $\mathrm{a}, \mathrm{c}, \mathrm{f}, \mathrm{g}, \mathrm{i}, \mathrm{j}, \mathrm{k}$ \\
\hline BG Biomass ( $\left.\mathrm{g} \mathrm{DW} \mathrm{m}^{-2}\right)$ & - & $17.07-33.71$ & - & $\mathrm{a}, \mathrm{c}, \mathrm{f}, \mathrm{g}, \mathrm{i}, \mathrm{j}, \mathrm{k}$ \\
\hline Productivity ( $\left.\mathrm{g} \mathrm{C} \mathrm{m}^{-2} \mathrm{y}^{-1}\right)$ & $\mathrm{nr}$ & 5 & - & $\mathrm{f}$ \\
\hline \multicolumn{5}{|l|}{ b. Biochemical } \\
\hline Total chlorophyll $(a+b)$ & $\mathrm{nr}$ & $0.04-0.13$ & & $\mathrm{n}$ \\
\hline Protein $\left(\mathrm{mg} \mathrm{g}^{-1}\right)$ & 393.12 & $0.70-132.0$ & $\mathrm{p}$ & $\mathrm{n}, \mathrm{o}$ \\
\hline Carbohydrate $\left(\mathrm{mg} \mathrm{g}^{-1}\right)$ & 476.18 & $2.93-161$ & $\mathrm{p}$ & $\mathrm{n}, \mathrm{o}$ \\
\hline Lipid $\left(\mathrm{mg} \mathrm{g}^{-1}\right)$ & $\mathrm{nr}$ & $0.9-1.05$ & - & $\mathrm{n}, \mathrm{o}$ \\
\hline Tannin $\left(\mathrm{mg} \mathrm{g}^{-1}\right)$ & $\mathrm{nr}$ & $1.03-1.35$ & - & $\mathrm{n}, \mathrm{o}$ \\
\hline Phenol $\left(\mathrm{mg} \mathrm{g}^{-1}\right)$ & $\mathrm{nr}$ & $2.1-3.75$ & - & $\mathrm{n}, \mathrm{o}$ \\
\hline Organic carbon $(\%)$ & 30 & $\mathrm{nr}$ & $\mathrm{p}$ & - \\
\hline $\mathrm{C}: \mathrm{N}$ & 03:07 & $\mathrm{nr}$ & $\mathrm{p}$ & - \\
\hline
\end{tabular}

a) Savurirajan et al., 2015; b) Ramamurthy et al., 1992; c) Parthasarathy et al., 1998 d) Untawale and Jagtap, 1977; e) Kaladharan, 2004; f) Bharathi et al., 2014; g) Mathews et al., 2010; h) Manikandan et al., 2011a; i) Manikandan et al., 2011b; j) Manikandan et al., 2011c; k) Kalimuthu et al., 1995; 1) Kaladharan et al., 2018; m) Jagtap and Untawale, 1981; n) Pradheeba et al., 2011; o) Nobi et al., 1993; p) Jagtap and Untawale, 1981 
Table.3 Various ecosystem services of $H$. beccarii from the coast of India. Ecosystem service variables are adopted from Nordlund et al., (2016) and modified for H. beccarii for Indian scenarios. Water Quality Index (WQI), Sea Life Index (SLI)

\begin{tabular}{lll}
\hline Sl. no & Ecosystem Service & Observations \\
\hline 1 & Fish habitat & Nursery and habitat \\
2 & Invertebrate habitat & $\begin{array}{l}\text { Habitat for invertebrates like polychaetes, nematodes, } \\
\text { gastropods, Molluscs, etc }\end{array}$
\end{tabular}

$3 \quad$ Nursery (habitat for Habitat for juveniles,

$4 \quad$ Seagrass as food for

Food for dugongs and turtles coastal organisms (turtles, dugongs and herbivore fishes)

5 Pharmaceuticals/Bioactive compounds

6 Coastal protection

$7 \quad$ Sediment stabilization

$8 \quad$ Productivity

9 Ecological connectivity with mangroves

11 Source of information (water quality, bioindicator of coastal contamination) of Metals

\section{References}

Nair, 2002; Singh et al., 2004; Mathews et al., 2010; Kaladharan and Asokan, 2012; Kaladharan et al., 2018

Nair, 2002; Singh et al., 2004;

Ranjitham et al., 2008; Nedumaran et al., 2009; Mathews et al., 2010a;

Kaladharan et al., 2018; Meeran et al., 2018

Nair, 2002; Singh et al., 2004; Mathews

et al., 2010a; Kaladharan et al., 2018

Gamboj, 2012; Anand, 2012;

Kaladharan et al., 2018

High phenolic and flavonoid compounds, antioxidants, Antidiabetic activity, anticancer compounds

Neelima et al., 2015; Vani et al., 2018; Kar et al., 2019; Vanitha et al., 2020

Kaladharan et al., 2018

Jagtap et al., 2003; Kaladharan et al., 2018

Ghevade and Joshi, 1980; Nobi 1993

Jagtap et al., 2003; Purvaja et al., 2018

Healthy seagrass biodiversity

Use of seagrass ecosystems for WQI, SLI, Bioindicators

Mathews et al., 2010a; Purvaja et al., 2018, Jagtap, 1983 


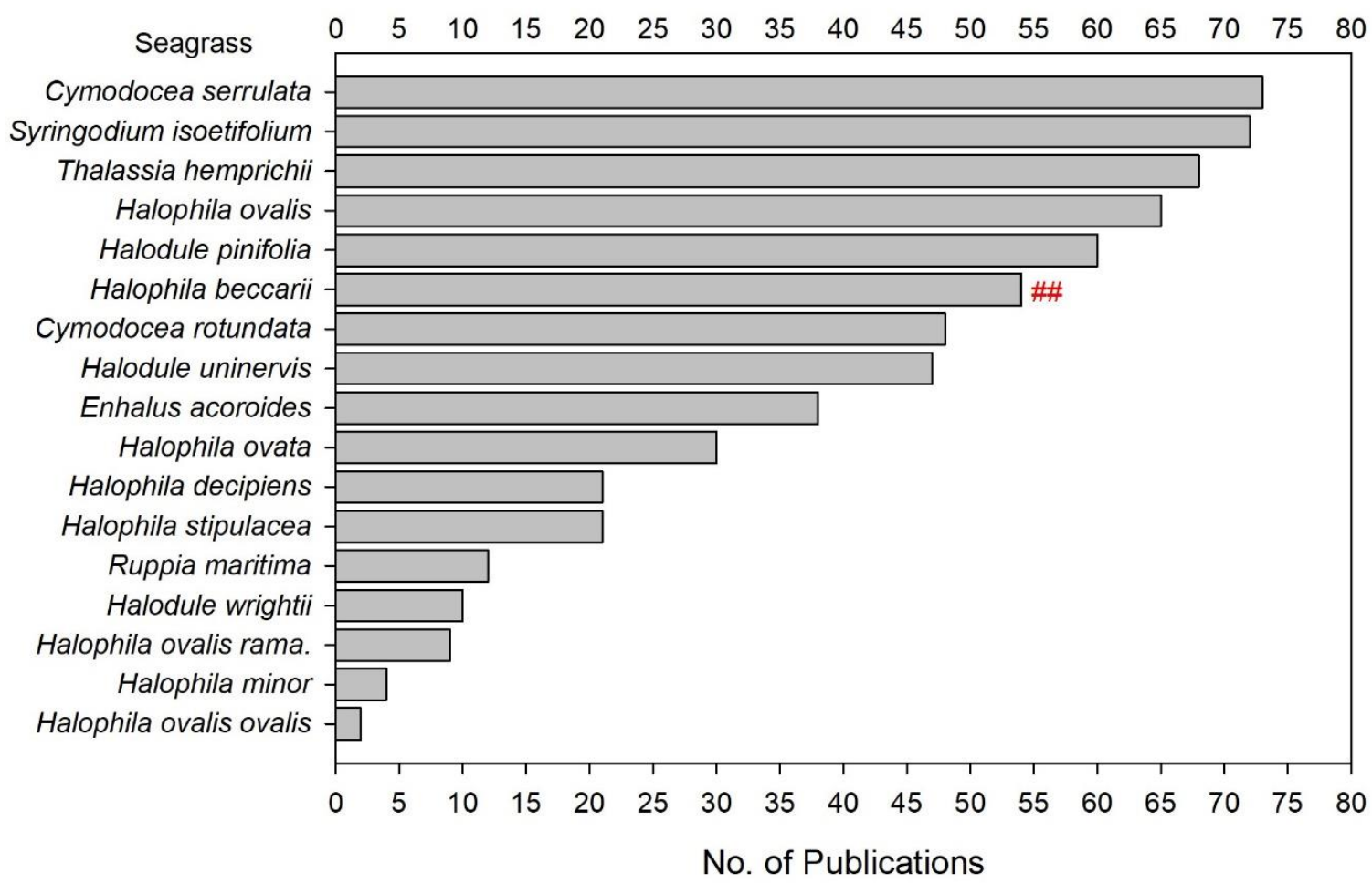

Fig.1. Number of publications from 1970 to 2020 on various seagrass species of India including $H$. beccarii (red \#). 


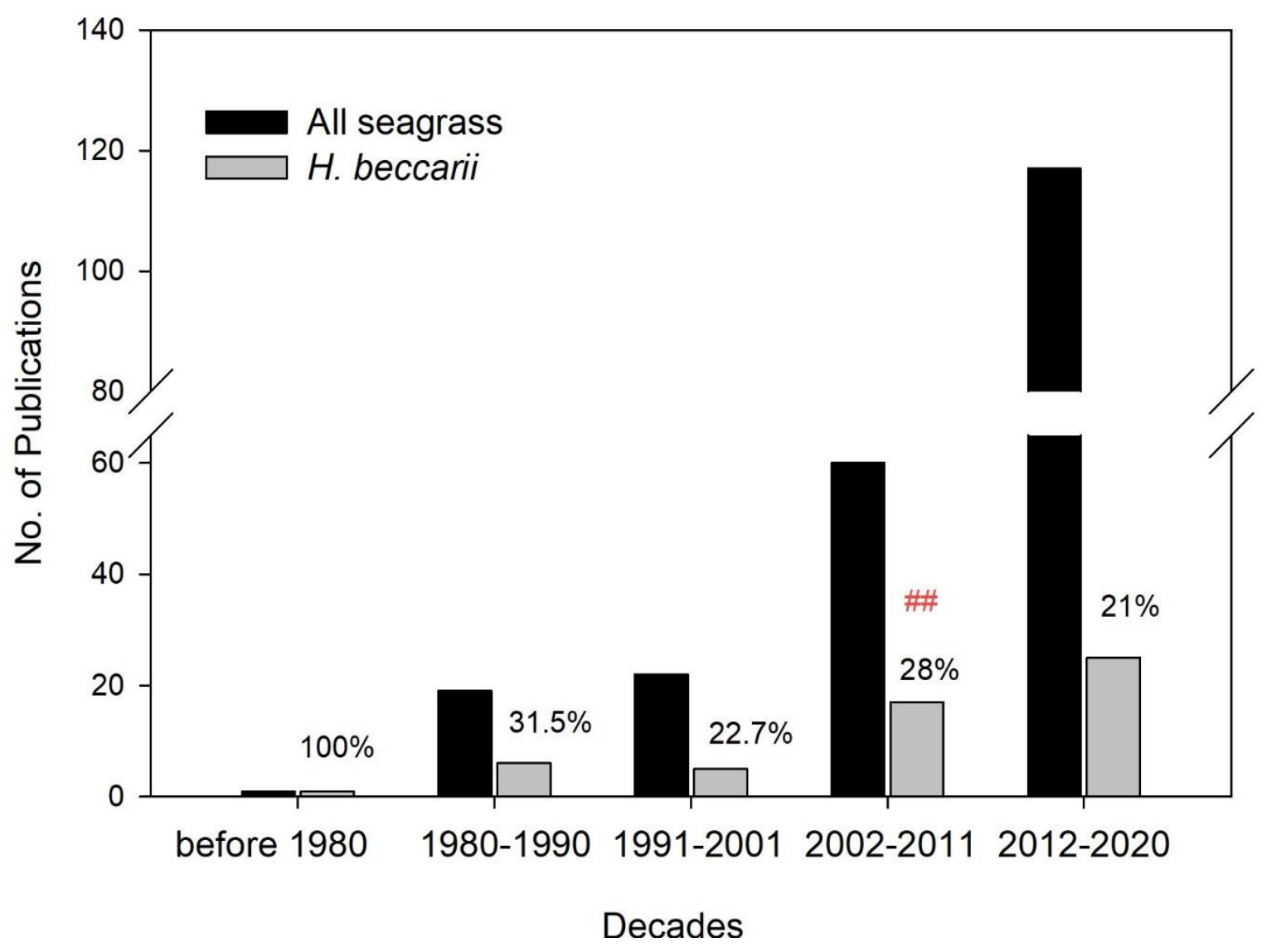

Fig.2. Decade wise number of publications on $H$. beccarii from the coast of India. The number of $H$. beccarii publication out of the total number of publications for each decade is provided as percentage. Red \# indicate the year $H$. beccarii was declared as Vulnerable by IUCN. 


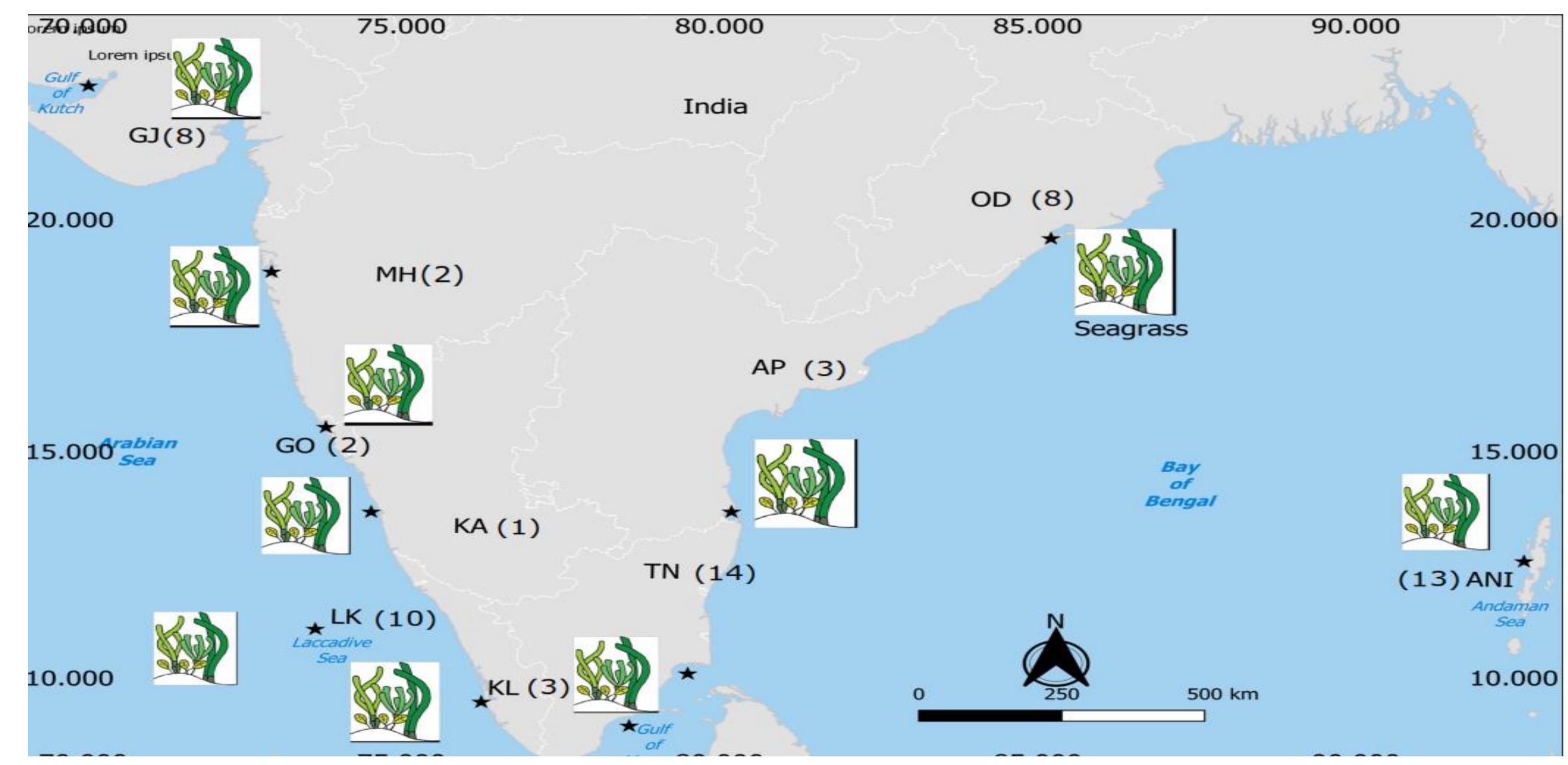

3 Fig.3. Map showing the States and islands that have seagrass ecosystems around the east and west coast of India. Numbers in bracket for each 4 state indicate the number of seagrass species found in each state including H. beccarii. Odisha (OD), Andhra Pradesh (AP), Andaman and Nicobar 5 Islands (ANI), Tamil Nadu (TN), Kerala (KL), Lakshadweep island (LK)*, Karnataka (KA), Goa (GO), Maharashtra (MH), Gujarat (GJ). *There is no report for presence of $H$. beccarii at LK. 
No. of Publications

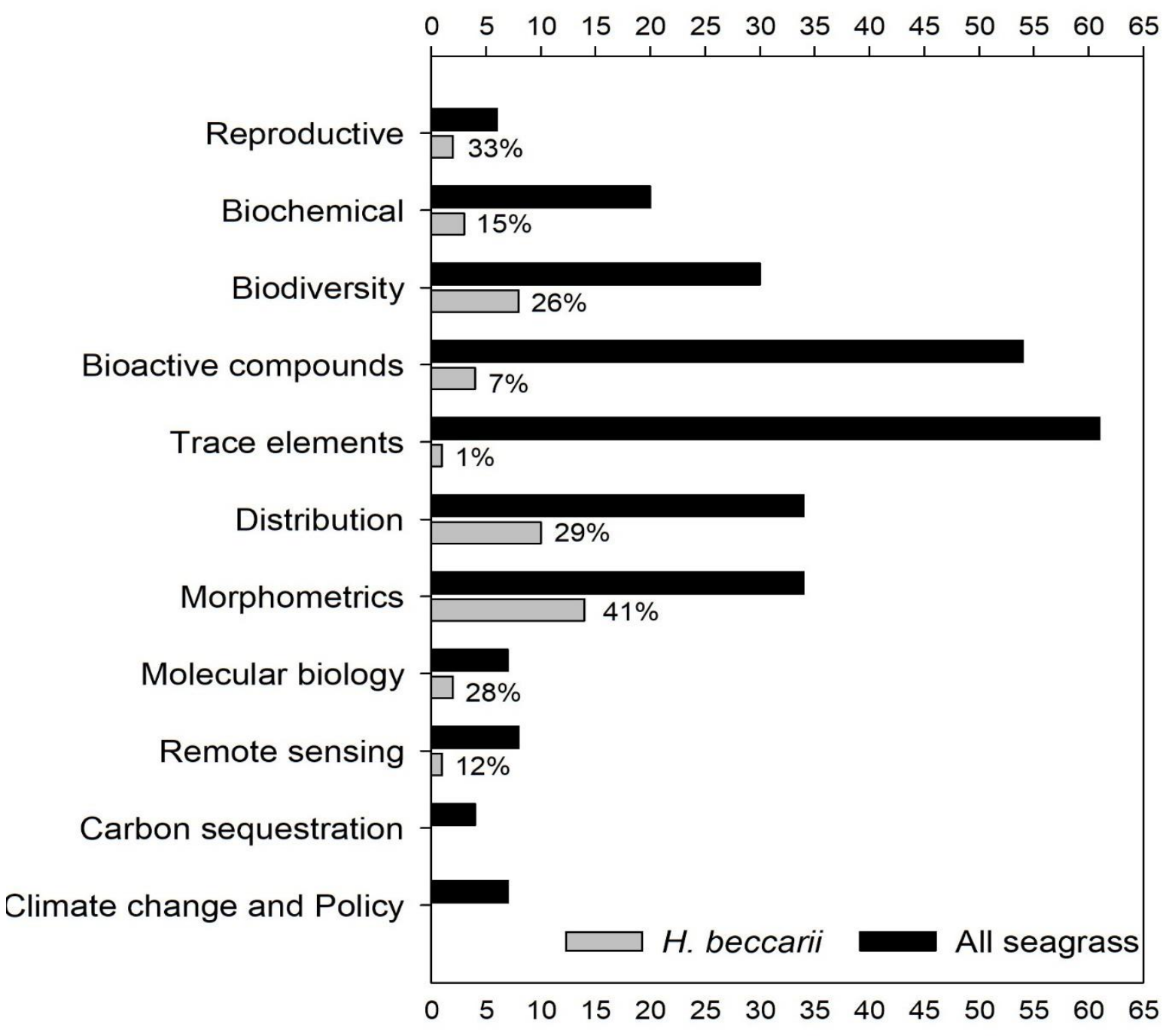

9 Fig.4. Number of publications on various parameters of all seagrass species and that of $H$. 10 beccarii in India. The number in percentage indicate the contribution of $H$. beccarii in each 11 variable. 


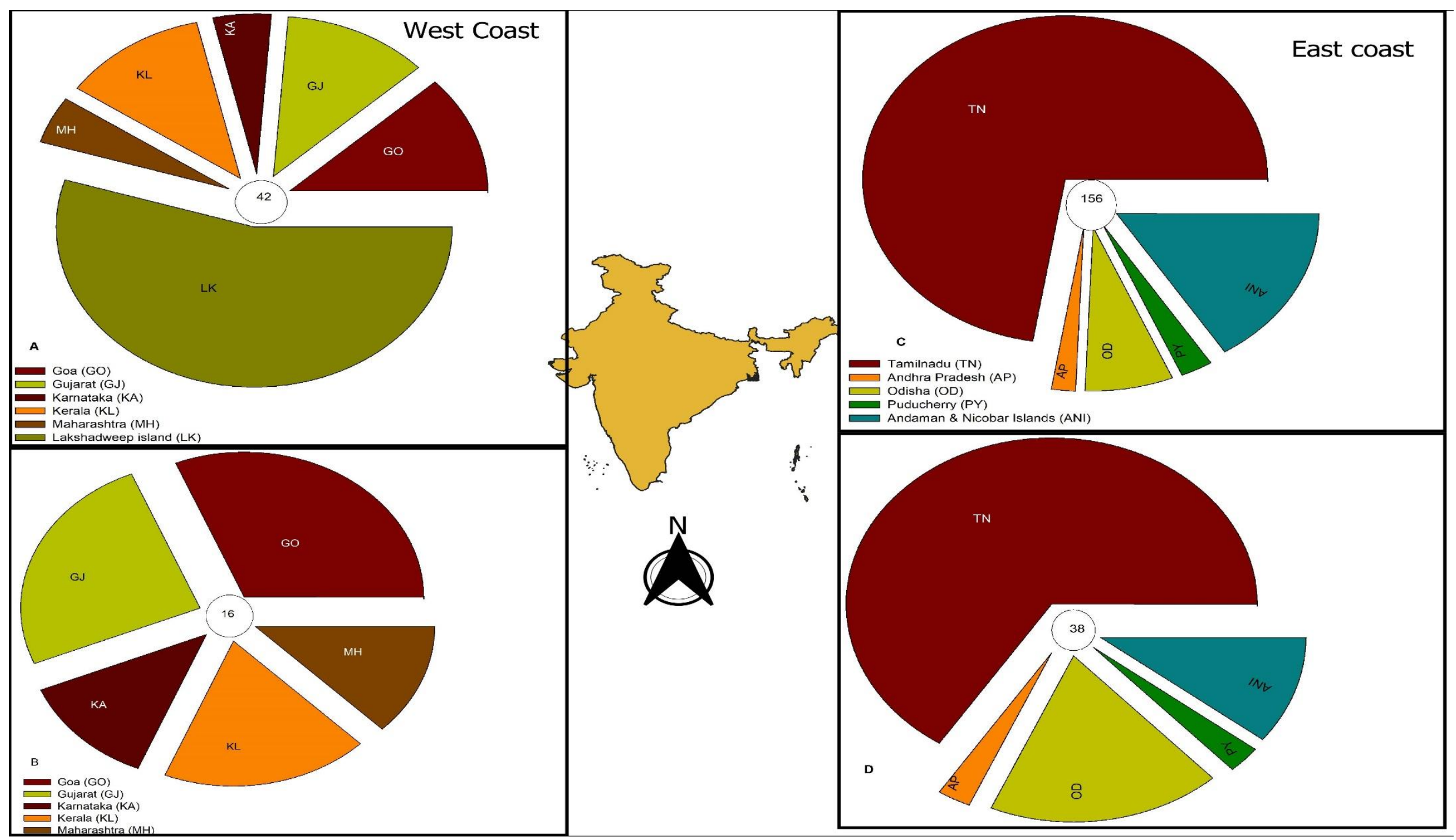

Fig.5. Total number of seagrass publications state wise of all seagrass species in the West coast (A) and for only $H$. beccarii (B) and East coast (C) and H. beccarii (D). The number in the middle of the circle for each pie chart represents the total number of publications. 


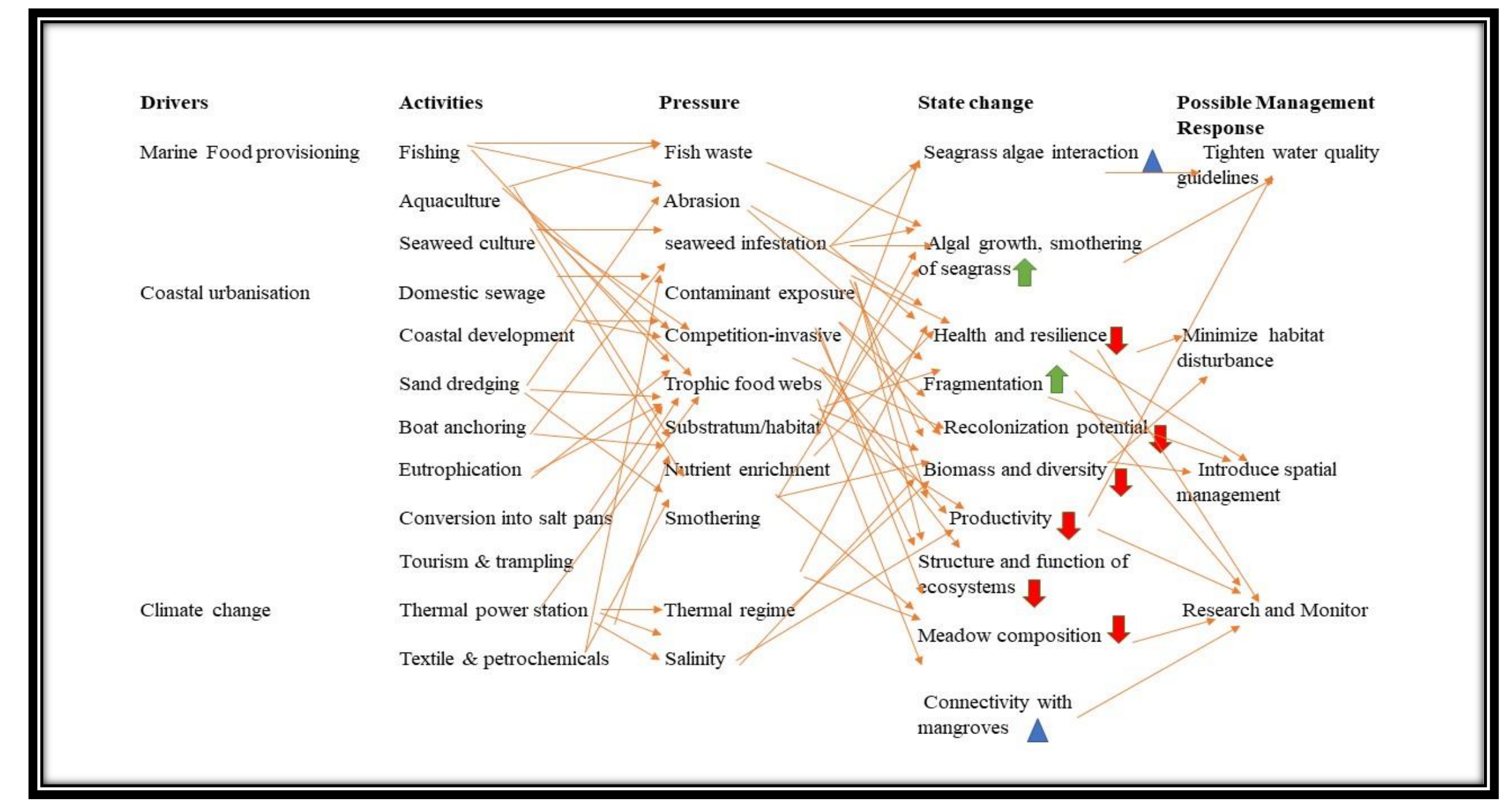

Fig.6 The DAPSIR model for $H$. beccarii from the coast of India. Green arrows indicate (increase), red arrows indicate (decrease) and blue triangles indicate (not studied). The Drivers, Activities, Pressures were collected from the literature survey and the State of change and Possible

17 triangles indicate (not studied). The Drivers, Activities, Pressures were co
18 management response were adopted.

\title{
Preprints (urww.preprints.org) | NOT PEER-REVIEWED | Posted: 5 August 2020
}

17 triangles indicate (not studied). The Drivers, Activities, Pressures were co

6

mangrove

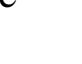

6


